\title{
RESEARCH
}

\section{Circulating aryl hydrocarbon receptor-interacting protein (AIP) is independent of $\mathbf{G H}$ secretion}

\author{
Marko Stojanovic ${ }^{1,2}$, Zida Wu ${ }^{3}$, Craig E Stiles ${ }^{4}$, Dragana Miljic ${ }^{1,2}$, Ivan Soldatovic ${ }^{2,5}$, Sandra Pekic ${ }^{1,2}$, Mirjana Doknic ${ }^{1,2}$, \\ Milan Petakov ${ }^{1,2}$, Vera Popovic ${ }^{2}$, Christian Strasburger ${ }^{3}$ and Márta Korbonits ${ }^{4}$ \\ ${ }^{1}$ Neuroendocrinology Department, Clinic for Endocrinology, Diabetes and Metabolic Diseases, Clinical Centre of Serbia, Belgrade, Serbia \\ 2University of Belgrade, Medical Faculty, Belgrade, Serbia \\ ${ }^{3}$ Department of Medicine for Endocrinology, Diabetes and Nutritional Medicine, Charité Universitätsmedizin, Campus Mitte, Berlin, Germany \\ ${ }^{4}$ Centre for Endocrinology, William Harvey Research Institute, Barts and the London School of Medicine and Dentistry, Queen Mary University of London, \\ London, UK \\ ${ }^{5}$ Insitute of Medical Statistics and Informatics, Belgrade, Serbia
}

Correspondence should be addressed to M Stojanovic: markostoj@yahoo.com

\begin{abstract}
Background: Aryl hydrocarbon receptor-interacting protein (AIP) is evolutionarily conserved and expressed widely throughout the organism. Loss-of-function AIP mutations predispose to young-onset pituitary adenomas. AIP co-localizes with growth hormone in normal and tumorous somatotroph secretory vesicles. AIP protein is detectable in circulation. We aimed to investigate possible AIP and GH co-secretion, by studying serum AIP and GH levels at baseline and after GH stimulation or suppression, in GH deficiency (GHD) and in acromegaly patients.

Subjects and methods: Insulin tolerance test (ITT) was performed in GHD patients ( $n=13)$ and age-BMI-matched normal GH axis control patients $(n=31)$. Oral glucose tolerance test (OGTT) was performed in active acromegaly patients $(n=26)$ and age-BMI-matched normal GH axis control patients $(n=18)$. In-house immunometric assay was developed for measuring circulating AIP.

Results: Serum AIP levels were in the $0.1 \mathrm{ng} / \mathrm{mL}$ range independently of gender, age or BMI. Baseline AIP did not differ between GHD and non-GHD or between acromegaly and patients with no acromegaly. There was no change in peak, trough or area under the curve during OGTT or ITT. Serum AIP did not correlate with GH during ITT or OGTT. Conclusions: Human circulating serum AIP in vivo was assessed by a novel immunometric assay. AIP levels were independent of age, sex or BMI and unaffected by hypoglycaemia or hyperglycaemia. Despite co-localization in secretory vesicles, AIP and GH did not correlate at baseline or during GH stimulation or suppression tests. A platform of reliable serum AIP measurement is established for further research of its circulatory source, role and impact.
\end{abstract}

Key Words
- GH secretion
- pituitary adenoma
- hypopituitarism
- ITT
- OGTT
- acromegaly
- FIPA
- AIP

\section{Introduction}

Aryl hydrocarbon receptor-interacting protein (AIP) is a molecular co-chaperone to heat-shock proteins. Interest in its nature and function originated from the discovery that heterozygous loss-of-function AIP mutations predispose to pituitary adenomas $(\mathrm{PA})(1,2,3)$. AIP protein is highly conserved evolutionarily and widely distributed https://ec.bioscientifica.com

https://doi.org/10.1530/EC-19-0082 (c) 2019 The authors Published by Bioscientifica Ltd

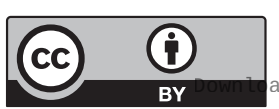

This work is licensed under a Creative Commons Attribution 4.0 International License. ded from Bioscientifica.com at 04/26/2023 10:05:42AM 
throughout the organism (4). Homozygous Aip deletion leads to embryonic lethality in both mammalian and invertebrate models $(5,6)$.

The AIP protein is a $37 \mathrm{kDa}, 330$ amino-acid member of FKBP (FK506-binding protein) family. The highly conserved C-terminal TPR motifs mediate many of its protein-protein interactions $(7,8,9)$. A long half-life of AIP suggests its abundance and structural complexity (10). AIP was originally discovered as a binding partner of aryl hydrocarbon receptor (AhR), which is best known for mediating the effects of environmental toxins such as dioxin $(11,12,13)$. AIP may play diverse biological roles through interactions with various other interacting partners (14). Some of its interactions involve antioxidative and anti-proliferative pathways or mechanisms instrumental in the regulation of cytoskeletal organization and integrity of adherens junction $(10,15)$.

AIP mutations were found in $20 \%$ of patients with familial isolated pituitary adenoma (FIPA) and in 25\% of sporadic somatotropinomas of childhood onset (16, 17). Most often these are invasive GH- or PRL-secreting macroadenomas, resistant to somatostatin analogue (SA) treatment $(17,18)$. AIP is thought to play an important role in the response to SA in acromegaly (19). Neither the exact mechanism of AIP influence on proliferation inhibition, nor its possible role in normal pituitary function is known.

AIP mRNA was expressed in normal pituitary tissue and in sporadic somatotropinomas, prolactinomas, corticotropinomas and non-functioning pituitary adenoma. In normal pituitary tissue, doubleimmunofluorescence staining detected AIP exclusively in GH and PRL cells, sub-localized by electron microscopy to secretory vesicles. Unlike the normal pituitary, in PAs, AIP protein was expressed in somatotropinomas, prolactinomas, corticotropinomas and non-functioning pituitary adenomas (3). However, subcellular AIP distribution depended on the adenoma cell type. Only in somatotropinomas was AIP staining detected in the secretory vesicles, similarly to normal human GH cells and rat pituitary-derived GH3 cells, whereas being distributed within the cytoplasm in other PA subtypes (3). These findings raised an interest in the question of AIP being released from secretory vesicles of somatotrophs or lactotrophs.

Several studies demonstrated decrease in basal or stimulated GH secretion in non-adenomatous GH3 cells after endogenous Aip knockdown or transfection with mutated AIP $(20,21)$. TRIP8b - a protein involved in ACTH release - shares similarity in the TPR domain with AIP, which added to the interest in a potential corresponding role of AIP in GH release (22). Cellular mechanisms were identified linking AIP to synaptic vesicles, which share many conserved features with endocrine secretory vesicles (23).

Many of molecular chaperones and protein-folding catalysts can be secreted from cells and function additionally as pleiotropic signals for a variety of cells principally involved in immunity and inflammation (24). Even FKBP family members were also found to be secreted into the systemic circulation acting on distant cell-surface receptors $(25,26)$. The presence and dynamic responsiveness of AIP protein in human circulation was demonstrated by plasma proteomics (27).

All these data gave rise to our hypothesis that AIP could be co-secreted with GH. We have aimed to study the correlation of constitutive and dynamic AIP and $\mathrm{GH}$ secretion using in vivo human models of normal GH secretion, patients with GH deficiency (GHD) and patients with GH hypersecretion - acromegaly.

\section{Subjects and methods}

\section{Subjects}

A total of 88 adult subjects were divided into four groups based on their GH secretion status. Groups consisted of patients with GH deficiency - GHD $(n=13)$, control patients with preserved GH secretion (non-GHD, NGHD, $n=31$ ), patients with active acromegaly (AA, $n=26)$ and control patients with preserved (normal) GH suppressibility (NGHS, $n=18$ ). Demographic and anthropometric characteristic of investigated subjects are summarized in Table 1. Patients with GHD and NGHD were matched for age and BMI. Six of the GHD patients had isolated GHD and seven had additional pituitary hormone deficiencies, two of which had complete anterior pituitary hormone deficiency with additional central diabetes insipidus in one of the two. The AA and NGHS groups were matched for age, sex and BMI. The AA patients (16 with macroadenoma and 10 with microadenoma) were either newly diagnosed or persistent after treatment. Seven patients have previously received somatostatin analogue treatment; none at the time of testing. One had previously received dopamine agonists. In the NGHS group, 12 patients with acromegaly were cured by surgery and six subjects had non-functioning pituitary adenomas with normal GH dynamics.

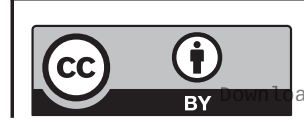

This work is licensed under a Creative Commons Attribution 4.0 International License. ded from Bioscientifica.com at 04/26/2023 10:05:42AM 
Table 1 Demographic and anthropometric characteristics of investigated subjects.

\begin{tabular}{|c|c|c|}
\hline & \multicolumn{2}{|c|}{ Group } \\
\hline & GHD & NGHD \\
\hline$N$ & 13 & 31 \\
\hline Age (years) & $38.8 \pm 3.76$ & $35.1 \pm 2.42$ \\
\hline Gender (female) & $5(38.5 \%)$ & $22(71.0 \%)$ \\
\hline $\mathrm{BMI}\left(\mathrm{kg} / \mathrm{m}^{2}\right)$ & $27.37 \pm 1.54$ & $26.18 \pm 1.54$ \\
\hline
\end{tabular}

Data are expressed as mean and S.E. (age and BMI) or as \% (gender). ${ }^{\mathrm{a}}$-test; ${ }^{\mathrm{b}} \mathrm{Chi}$-square test.

GHD was defined by the GH peak in insulin tolerance test (ITT) $<3.0 \mathrm{ng} / \mathrm{mL}$ or in the presence of multiple pituitary hormone deficiencies and IGF-1 below the age- and population-specific reference range. Preserved GH axis was defined by peak GH in ITT $>5 \mathrm{ng} / \mathrm{mL}$ following a blood glucose nadir of $\leq 2.2 \mathrm{mmol} / \mathrm{L}$ (28). Active acromegaly was defined in the presence of clinical manifestations, unsuppressible $\mathrm{GH}$ in oral glucose tolerance test (OGTT, nadir $>1.0 \mathrm{ng} / \mathrm{mL}$ ) and elevated IGF-1 (above age-related reference range). Active acromegaly was excluded by suppressible GH in OGTT $<1.0 \mathrm{ng} / \mathrm{mL}$ (29). All subjects were assessed by a physical examination and routine biochemical analysis of serum and urine. Subjects with severe renal insufficiency (eGFR $<30 \mathrm{~mL} / \mathrm{min}$ ) were excluded. All patients were informed in detail of the study procedures and their written consent was obtained in accordance to the study approval by the Ethics Committee of Belgrade University Medical Faculty (Approval No 29/XII-23). The research was conducted at the Department for Neuroendocrinology, Clinic for Endocrinology, Clinical Centre of Serbia, from July 2014 to December 2015.

\section{Dynamic tests of GH secretion}

ITT was performed after excluding contraindications (history or risk of seizures or coronary heart disease) by standard departmental procedure: after an i.v. bolus of Actrapid-Insulin $0.15 \mathrm{IU} / \mathrm{kg}$, cubital vein blood samples were taken via i.v. cannula at $0,30,60,90$ and $120 \mathrm{~min}$ for serum analysis of GH, PRL, cortisol and AIP. Tests were initiated at 8:00 h in a supine position after overnight rest and fasting.

OGTT was performed after excluding contraindications (diabetes mellitus) by standard departmental procedure with oral application of $75 \mathrm{~g}$ glucose solution at 8:00 h after an overnight fasting and resting, followed by cubital vein blood sampling for GH and AIP analysis via i.v. cannula at 0 , 30, 60, 90 and $120 \mathrm{~min}$ after glucose load.

\section{Hormonal analysis}

All serum samples were stored at $-80^{\circ} \mathrm{C}$ until analysed for GH, cortisol and PRL at the Clinic for Endocrinology, Diabetes and Metabolic Diseases, Clinical Centre of Serbia. GH was measured by immunoradiometric assay HGH-RIA CT Cisbio Bioassays, Codolet, France (Calibrator WHO IS 98/574; limit of detection (LOD) $0.01 \mathrm{ng} / \mathrm{mL}$ within-run coefficients of variation (CV) $2.1 \%$ (for mean $1.4 \mathrm{ng} / \mathrm{mL}$ ) and $1.3 \%$ (for mean $21.0 \mathrm{ng} / \mathrm{mL}$ ) between-run CV $4.5 \%$ (for mean $1.3 \mathrm{ng} / \mathrm{mL}$ ) $5.0 \%$ (for mean $5.9 \mathrm{ng} / \mathrm{mL}$ ) $3.8 \%$ (for mean $8.1 \mathrm{ng} / \mathrm{mL}$ ) and $4.8 \%$ (for mean $12.4 \mathrm{ng} / \mathrm{mL}$ ). Cortisol was measured by CORT-CT2 Cisbio Bioassays, Codolet, France (intra-assay CV 5.3\% (for mean $64 \mathrm{nmol} / \mathrm{L}$ ) 3.6\% (for mean $251 \mathrm{nmol} / \mathrm{L}$ ) $3.7 \%$ (for mean $686 \mathrm{nmol} / \mathrm{L}$ ); inter-assay CV $5.7 \%$ (for mean $63 \mathrm{nmol} / \mathrm{L}$ ), $8.1 \%$ (for mean $222 \mathrm{nmol} / \mathrm{L}$ ) and $6.7 \%$ (for mean $565 \mathrm{nmol} / \mathrm{L}$ ) LOD $6.6 \mathrm{nmol} / \mathrm{L}$ ). Prolactin was measured by immunoradiometric assay PRL-IRMA DIAsource ImmunoAssays, Louvain-la-Neuve, Belgium ((intra-assay CV 3.3\% (for mean $7.5 \mathrm{ng} / \mathrm{mL}$ ), $5.2 \%$ (for mean $26.6 \mathrm{ng} / \mathrm{mL}$ ); inter-assay CV $9.2 \%$ (for mean $7.4 \mathrm{ng} / \mathrm{mL}$ ) and $4.5 \%$ (for mean $49.1 \mathrm{ng} / \mathrm{mL}$ )). IGF-1 was measured using Siemens Immulite 2000 assay (calibrator WHO IS $87 / 518$ ), LOD $20 \mathrm{ng} / \mathrm{mL}$, highest measurable value $1600 \mathrm{ng} / \mathrm{mL}$, intra-assay CV $3.9 \%$ at $77 \mathrm{ng} / \mathrm{mL}, 6.5 \%$ at $169 \mathrm{ng} / \mathrm{mL}, 2.9 \%$ at $380 \mathrm{ng} / \mathrm{mL}, 3.0 \%$ at $689 \mathrm{ng} / \mathrm{mL}, 2.3 \%$ at $1053 \mathrm{ng} / \mathrm{mL}, 2.4 \%$ at $1358 \mathrm{ng} / \mathrm{mL}$; inter-assay CV $7.7 \%$ at $77 \mathrm{ng} / \mathrm{mL}, 5.4 \%$ at $169 \mathrm{ng} / \mathrm{mL}, 7.4 \%$ at $380 \mathrm{ng} / \mathrm{mL}, 8.1 \%$ at $689 \mathrm{ng} / \mathrm{mL}, 3.7 \%$ at $1053 \mathrm{ng} / \mathrm{mL}$ and $4.7 \%$ at $1358 \mathrm{ng} / \mathrm{mL}$.

\section{Circulating AIP analysis}

All serum samples were stored at $-80^{\circ} \mathrm{C}$ until transported under secured temperature conditions for analysis performed at Department of Medicine for Endocrinology, Diabetes and Nutritional Medicine, Charité Universitätsmedizin, Campus Mitte, Berlin, Germany. All samples were uniformly analysed in a single batch by an in-house AIP assay. The LOD of the AIP assay was $0.068 \mathrm{ng} / \mathrm{mL}$. The intra-assay CVs were 3.1-4.9\%; inter-assay CVs were $8.2-13.5 \%$.

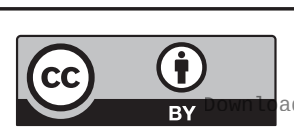

This work is licensed under a Creative Commons Attribution 4.0 International License. ded from Bioscientifica.com at 04/26/2023 10:05:42AM via free access 


\section{Production and purification of monoclonal and polyclonal antibodies against AIP}

Two-month-old female Balb/c mice were immunized with recombinant human AIP (produced in E. coli) dissolved in TiterMax adjuvant and injected intradermally (10 $\mu \mathrm{g}$ antigen/mouse). After 3-6 months of repeated immunization, the mice with the highest serum titres were killed and spleen cells were fused with NSO cells in the presence of polyethylene glycol using the hybridoma technique. Cells were grown in medium containing 20\% horse serum. Hybridoma cell supernatants were screened for anti-AIP activity after 10-12 days of culture using biotinylated AIP. Hybridoma cells corresponding to the highest signals of supernatants were cloned at least twice by limiting dilution. The IgG subclass of the monoclonal antibodies was determined. Large-scale production was carried out in protein-free medium. The polyclonal antiAIP antiserum was produced in rabbit immunized with recombinant AIP by the service of Davids Biotechnologie (Regensburg, Germany). The antibodies were affinity purified using an r-Protein A column and FPLC equipment. The pooled IgG-containing fractions were extensively dialyzed against PBS, divided into aliquots and stored at $-20^{\circ} \mathrm{C}$ until use.

\section{Biotinylation of monoclonal antibodies and AIP}

The purified monoclonal antibodies were biotinylated using a 75-fold molecular excess of the labelling reagent (biotinamidocaproate-N-hydroxysuccinimide ester) in the reaction. AIP was biotinylated using the same method but with 25 -fold molar excess of biotin.

\section{Assay standards}

The recombinant AIP diluted in assay buffer was used as the calibrator for the sandwich assay. To minimize matrix differences between serum samples and calibrators, additional BSA was added to the calibrators (final protein concentration 7\%).

\section{Time-resolved fluorescence sandwich immunoassay for AIP}

To increase AIP assay sensitivity for detection of all AIP molecules (including possible differently glycosylated forms), a sandwich assay was constructed with polyclonal and monoclonal antibodies combination. Microtitre plates were coated with polyclonal AIP antibodies ( $250 \mathrm{ng} /$ well) diluted in phosphate buffer
$(50 \mathrm{mmol} / \mathrm{L}, \mathrm{pH} 7.4)$ by overnight incubation at $4^{\circ} \mathrm{C}$. Detection antibodies were diluted in assay buffer (50 mmol/L Tris-(hydroxymethyl)-aminomethane, $154 \mathrm{mmol} / \mathrm{L} \mathrm{NaCl}, 20 \mathrm{~mol} / \mathrm{L}$ diethylenetriaminepentaacetic acid, $0.01 \%$ Tween 40 and $0.05 \% \mathrm{NaN}_{3}$ (pH 7.75)) BSA $(0.5 \%)$ and bovine-globulin $(0.05 \%)$ were added to reduce nonspecific binding. Washing buffer was prepared freshly for all experiments (PBS and 0.05\% Tween 20). The coated microtitre plates were washed, $25 \mu \mathrm{L}$ standards or samples were pipetted into each well together with $12.5 \mathrm{ng}$ biotinylated anti-AIP monoclonal antibody $1 \mathrm{~A} 11$ and $12.5 \mathrm{ng}$ biotinylated anti-AIP monoclonal antibody 3E1 in $75 \mu \mathrm{L}$ assay buffer. After an overnight incubation at $4^{\circ} \mathrm{C}$, the microtitre plates were washed three times with $0.3 \mathrm{~mL}$ wash buffer, and $10 \mathrm{ng}$ europium-labelled streptavidin was added into each well and incubated (60 min). After a six-fold washing step, the addition of $0.2 \mathrm{~mL}$ enhancement solution to each well, and a final incubation (10 min) on a horizontal plate shaker, the signal was read using the Victor multilabel counter.

\section{Statistical analysis}

Hormone concentrations were analysed as baseline values, and GH, cortisol and PRL peaks during ITT, nadir GH in OGTT, GH-, cortisol- and PRL-area under the curve ${ }_{0-120 \min }$ $\left(\right.$ AUC $\left._{0-120 \mathrm{~min}}\right)$ in ITT and GH-AUC ${ }_{0-120 \mathrm{~min}}$ in OGTT. Results are presented as count (\%), mean \pm standard error or median (25th-75th percentile) depending on data type and distribution. AIP values were expressed as median and interquartile range (25th and 75th percentile) of original non-normalized values. Serum AIP values were analysed as baseline, maximal and minimal values of AIP the dynamic tests, AIP AUC ${ }_{0-120 m i n}$ during the test and AIP Delta increment during test which was calculated as AIP Delta $=($ AIPmax - AIPbaseline $) /$ AIPbaseline. Integrated areas of secretion $\left(\mathrm{AUC}_{0-120 \mathrm{~min}}\right)$ were calculated using the trapezoidal method.

Normality of variable distribution was tested using the Kolmogorov-Smirnov and Shapiro-Wilk tests. Non-normally distributed variables were transformed using logarithmic transformation $\left(\log _{10}\right)$. Groups were compared for significance of difference using parametric (t-test) and nonparametric (chi-square, Mann-Whitney $U$ and Friedman) tests. To assess significance of correlation between variables, Spearman correlation was used. Friedman test was used to evaluate a significance of change between serum AIP values in different time points of the conducted tests (ITT and OGTT). SPSS Statistics, version

This work is licensed under a Creative Commons Attribution 4.0 International License. ded from Bioscientifica.com at 04/26/2023 10:05:42AM 
22 software was employed for the statistical analyses. $P$ values of $<0.05$ were regarded as indicating statistical significance.

\section{Results}

\section{Hormone responses to ITT and OGTT}

GH peak in ITT was significantly lower in the GHD group compared to NGHD group: $1.42 \pm 0.22 \mathrm{ng} / \mathrm{mL}$ vs $15.09 \pm 6.26 \mathrm{ng} / \mathrm{mL}(P<0.01)$. PRL peak in ITT was significantly lower in the GHD group compared to NGHD group: $26.76 \pm 3.69 \mathrm{ng} / \mathrm{mL}$ vs $114.59 \pm 14.17 \mathrm{ng} / \mathrm{mL}$ $(P<0.01)$. Cortisol peak in ITT was not significantly different in the GHD group compared to NGHD group: $710.0 \pm 51.3 \mathrm{ng} / \mathrm{mL}$ vs $636.9 \pm 23.6 \mathrm{ng} / \mathrm{mL}(P=0.21)$.

Nadir GH in OGTT was significantly lower in the NGHS than in the AA group: $0.29 \pm 0.05 \mathrm{ng} / \mathrm{mL}$ vs $11.27 \pm 2.90 \mathrm{ng} / \mathrm{mL}(P<0.01)$.

\section{AIP concentrations in serum}

\section{Impact of gender, age and BMI on serum AIP}

Baseline AIP, AIP max, AIP AUC and AIP Delta did not differ significantly between genders in either group (Supplementary Table 1, see section on supplementary data given at the end of this article). Baseline AIP, AIP max, AIP
AUC and AIP Delta did not correlate significantly with age in either group (Supplementary Table 2). Baseline AIP, AIP max, AIP AUC and AIP Delta did not correlate significantly with BMI in either group (Table 2).

\section{Impact of normal GH secretion on serum AIP}

Baseline AIP, AIP max, AIP AUC and AIP Delta did not differ significantly between the GHD and NGHD group (Fig. 1 and Supplementary Table 3). Baseline AIP, AIP max, AIP AUC and AIP Delta did not differ significantly between the AA and NGHS groups (Fig. 2 and Supplementary Table 4).

\section{Serum AIP during dynamic testing}

There was no difference in AIP values at 0, 30, 60, 90 and 120 min of the ITT in the GHD or NGHD groups nor in all ITT-tested subjects combined $(n=44)$ (Fig. 3 and Table 3$)$. There was no difference in AIP values at 0, 30, 60, 90 and 120 min of the OGTT in the AA or NGHS groups nor in all OGTT-tested subjects combined $(n=44)$ (Fig. 4 and Table 4$)$.

\section{Correlation of AIP with pituitary hormones during dynamic tests}

Baseline AIP did not correlate significantly with baseline GH, PRL or cortisol in the GHD or NGHD groups. AIPmax did not

Table 2 Correlation of baseline and dynamic AIP values with BMI.

\begin{tabular}{|c|c|c|c|c|}
\hline & Baseline AIP (ng/mL) & BMI $\left(\mathrm{kg} / \mathrm{m}^{2}\right)$ & $\boldsymbol{R}$ & $\boldsymbol{P}$ \\
\hline GHD & $0.155(0.112-0.326)$ & $27.37 \pm 1.54$ & -0.275 & 0.363 \\
\hline NGHD & $0.143(0.087-0.339)$ & $26.18 \pm 1.54$ & -0.062 & 0.751 \\
\hline $\mathrm{AA}$ & $0.096(0.067-0.159)$ & $29.13 \pm 1.52$ & 0.115 & 0.628 \\
\hline \multirow[t]{2}{*}{ NGHS } & $0.153(0.068-0.302)$ & $29.13 \pm 1.52$ & -0.448 & 0.072 \\
\hline & AIPmax (ng/mL) & BMI $\left(\mathrm{kg} / \mathrm{m}^{2}\right)$ & $\boldsymbol{R}$ & $P$ \\
\hline$\overline{\mathrm{GHD}}$ & $0.292(0.160-0.587)$ & $27.37 \pm 1.54$ & 0.074 & 0.809 \\
\hline NGHD & $0.278(0.146-0.562)$ & $26.18 \pm 1.54$ & 0.019 & 0.920 \\
\hline $\mathrm{AA}$ & 0.190 (0.106-0.247) & $29.13 \pm 1.52$ & -0.045 & 0.850 \\
\hline \multirow[t]{2}{*}{ NGHS } & $0.190(0.132-0.415)$ & $29.13 \pm 1.52$ & -0.282 & 0.273 \\
\hline & AIP AUC (ng/mL/120 min) & BMI $\left(\mathrm{kg} / \mathrm{m}^{2}\right)$ & $R$ & $P$ \\
\hline GHD & $25.90(13.03-50.03)$ & $27.37 \pm 1.54$ & 0.044 & 0.886 \\
\hline NGHD & $24.58(13.32-46.46)$ & $26.18 \pm 1.54$ & 0.025 & 0.898 \\
\hline $\mathrm{AA}$ & $12.85(9.97-22.16)$ & $29.13 \pm 1.52$ & 0.085 & 0.721 \\
\hline \multirow[t]{2}{*}{ NGHS } & $16.63(10.46-26.00)$ & $29.13 \pm 1.52$ & -0.350 & 0.168 \\
\hline & AIP Delta & BMI $\left(\mathrm{kg} / \mathrm{m}^{2}\right)$ & $\boldsymbol{R}$ & $P$ \\
\hline$\overline{\mathrm{GHD}}$ & $0.43(0.03-0.90)$ & $27.37 \pm 1.54$ & 0.210 & 0.491 \\
\hline NGHD & $0.69(0.23-1.32)$ & $26.18 \pm 1.54$ & 0.026 & 0.895 \\
\hline AA & $0.38(0.00-0.74)$ & $29.13 \pm 1.52$ & -0.007 & 0.977 \\
\hline NGHS & $0.14(0.00-0.59)$ & $29.13 \pm 1.52$ & 0.338 & 0.185 \\
\hline
\end{tabular}

Data are expressed as median and interquartile range (AIP values) or as mean and S.E. (BMI values).

$R$, Spearman's Rho.

https://ec.bioscientifica.com

https://doi.org/10.1530/EC-19-0082 (c) 2019 The authors Published by Bioscientifica Ltd

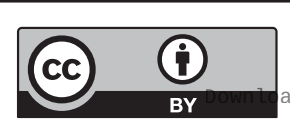

This work is licensed under a Creative Commons Attribution 4.0 International License. ded from Bioscientifica.com at 04/26/2023 10:05:42AM 
A
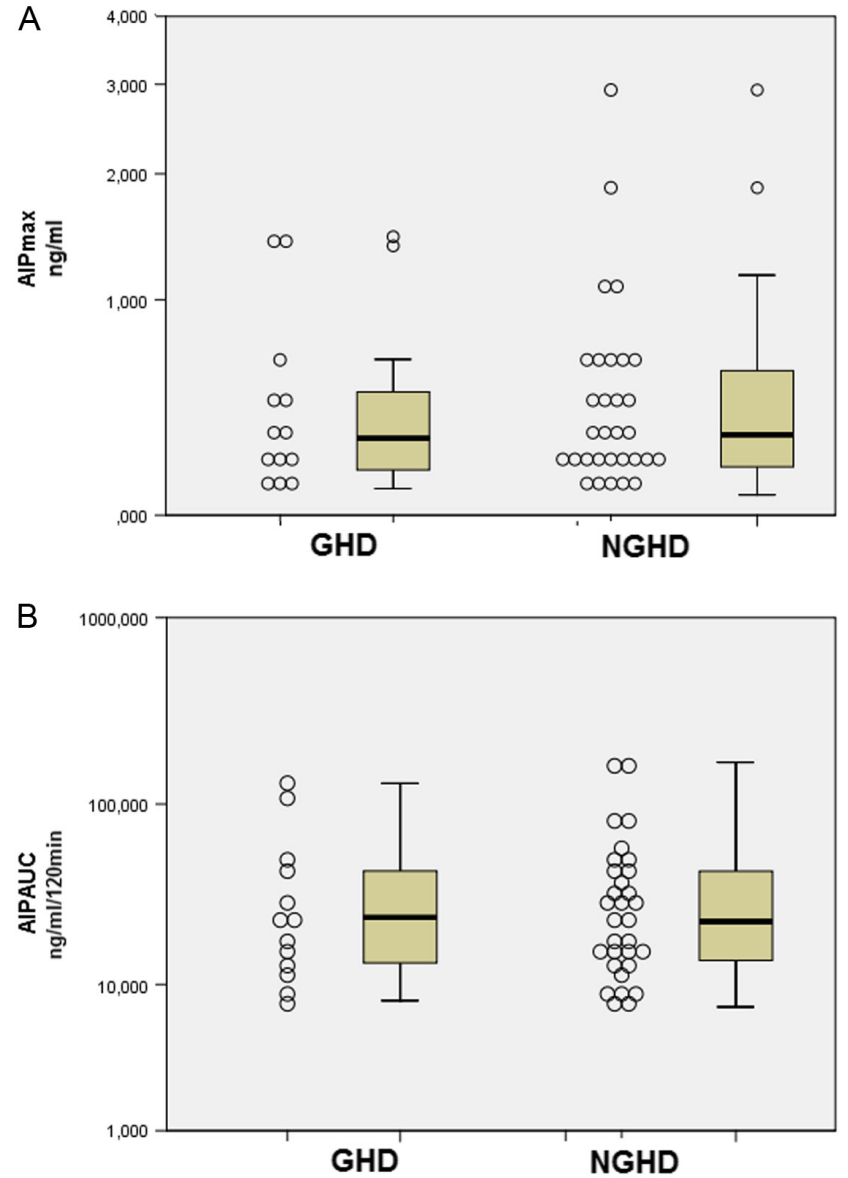

C

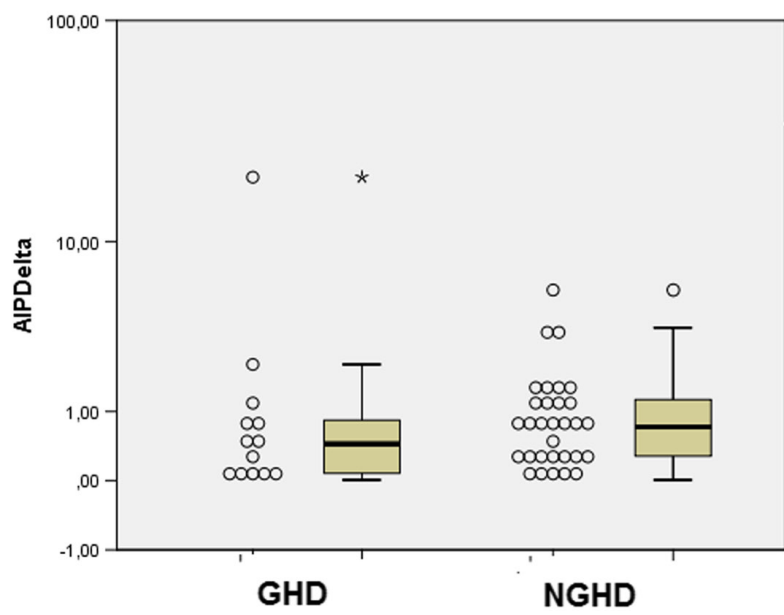

Figure 1

(A) Maximal AIP value in ITT (ng/mL, log scale) in GH deficiency (GHD) vs non-GHD (NGHD) patients. (B) AIP AUC in ITT (ng/mL/120 min, log scale) in GHD vs NGHD patients. (C) Delta AIP in ITT (log scale) in GHD vs NGHD patients.

correlate significantly with GHmax, PRLmax or cortisol peak in the GHD or NGHD groups. AIP AUC did not correlate significantly with GH, PRL or cortisol AUC in the GHD or NGHD groups (Tables 5, 6 and Supplementary Tables 5, 6).

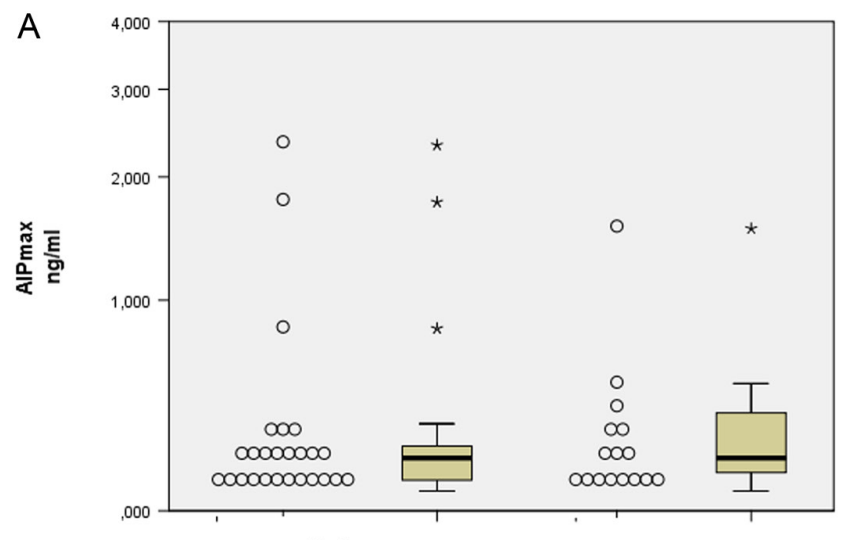

AA NGHS

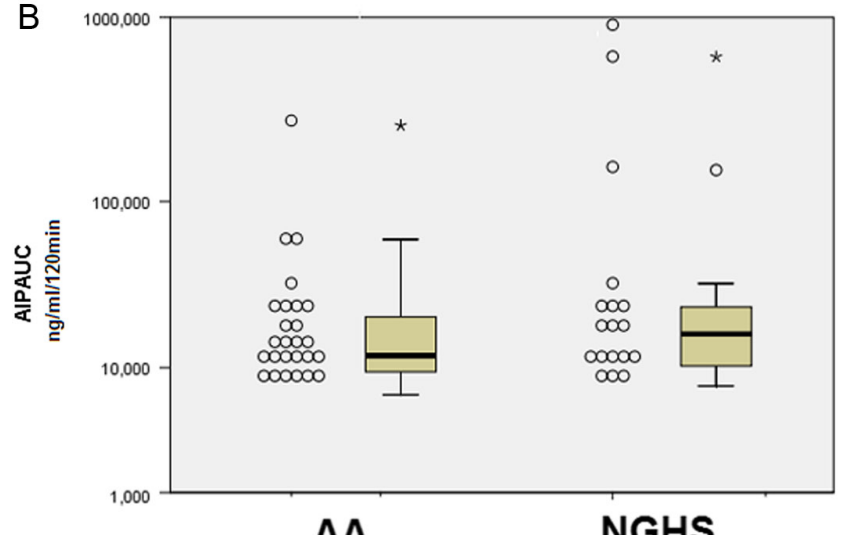

AA

NGHS

C

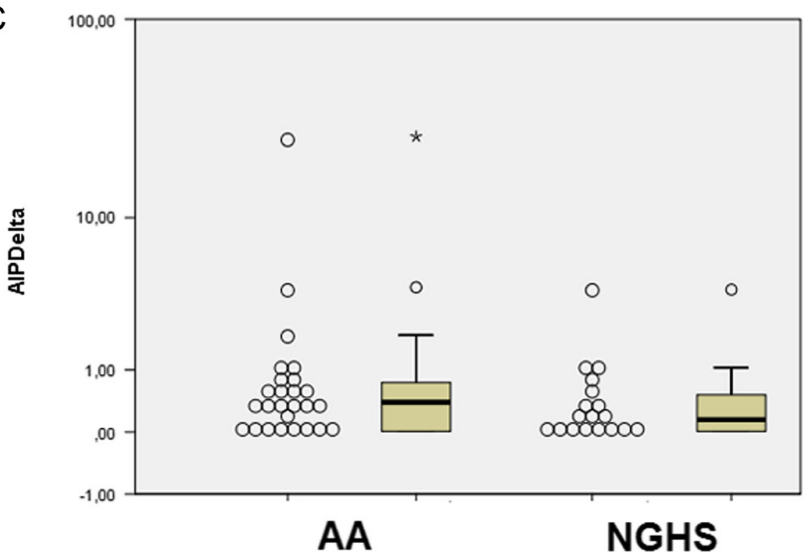

Figure 2

(A) Maximal AIP value during OGTT (ng/mL, log scale) in active acromegaly (AA) vs normal GH suppression (NGHS) patients. (B) AIP AUC in OGTT (ng/mL/120 min, log scale) in AA vs NGHS patients. (C) Delta AIP in OGTT (log scale) in AA vs NGHS patients.

\section{Discussion}

We set out to measure circulating AIP, as previous data suggested its localization within the secretory vesicles of somatotrophs in both normal and adenomatous pituitary. Using a novel immunometric assay, circulating serum AIP 


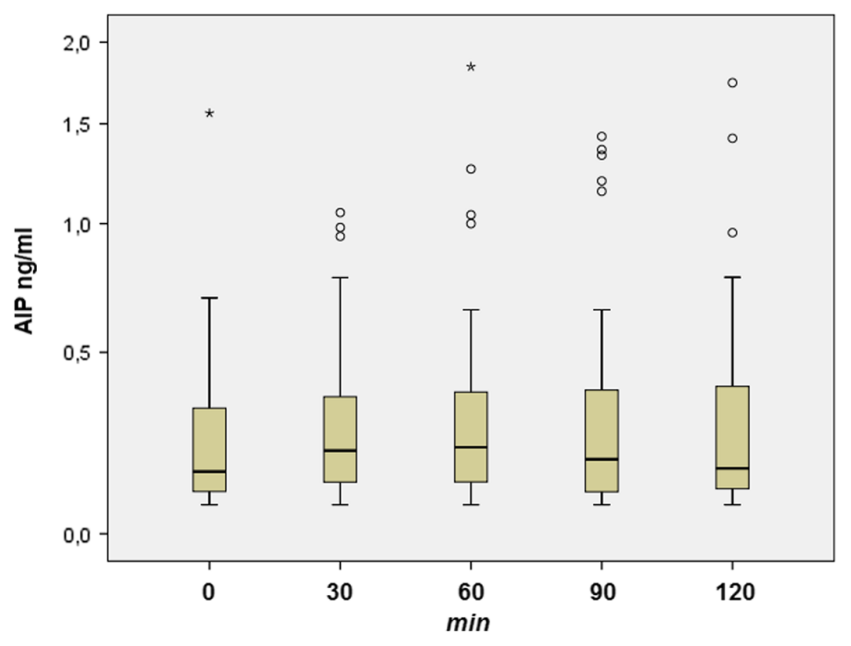

Figure 3

Serum AIP (ng/mL, log scale) in 0, 30, 60, 90 and 120 min of ITT (all 44 tested subjects).

levels were successfully and reliably measured during a five-point dynamic endocrine test in all 88 studied patients, in the $0.1 \mathrm{ng} / \mathrm{mL}$ range. Baseline serum AIP was independent of age, gender or BMI. Serum AIP levels in all investigated groups were stable over time in samples taken at 30-min intervals over 2-h course and were unchanged by severe hypoglycaemia (induced by ITT) or hyperglycaemia (induced by OGTT). Despite apparent AIP and GH co-localization in somatotroph secretory vesicles upon electromicroscopy and double fluorescence immunostaining (3), results of this study demonstrated that serum AIP concentrations are independent of GH elevation (baseline or during ITT) or suppression (baseline or during OGTT). No difference was observed in AIP levels (basal, maximal or integrated) between subjects with GH deficiency (GHD) or preserved GH secretion, nor between the subjects with active acromegaly (unsuppressibly elevated GH) versus those with normal GH suppressibility. Neither did serum AIP and GH correlate at baseline, nor during ITT or OGTT. Our results directly demonstrate that serum AIP is stable over time in human circulation despite significant oscillations in blood glucose, with no effect from severe hypoglycaemia or hyperglycaemia, a significant rise in GH, cortisol, PRL (directly) or ACTH (indirectly based on its physiological response to ITT).

Previous findings on plasma AIP, determined by the novel proteomics technology SOMAmer, indicated a significant increase in AIP levels following a highfat meal (three-fold rise from baseline over $6 \mathrm{~h}$ ) in dietresistant obese subjects (27). Our results in individuals with an average BMI of $28.4 \pm 0.8 \mathrm{~kg} / \mathrm{m}^{2}$ (all 44 OGTTtested subjects) indicate no change in serum AIP over $2 \mathrm{~h}$ following oral glucose load.

While the exact role of AIP in pituitary adenoma tumorigenesis is being intensively investigated, little is known about its role in normal pituitary function. Several molecular chaperones, in addition to their intracellular roles, were shown to be secreted from cells and function as distant mediators involved in immunity or inflammation (24). AIP is expressed in numerous tissues, but its subcellular localization to secretory vesicles was demonstrated only in pituitary somatotrophs and lactotrophs (3).

We considered several hypotheses to explain the observed divergence between previously demonstrated secretory vesicle co-localization of AIP and GH and absent co-secretion detectable in the systemic circulation. Previous examples related to pituitary and other endocrine cells provide possible paradigms mirroring our findings (30, 31, 32, 33, 34, 35, 36). FSH and LH are both released from the same gonadotroph cells but differ in dynamic responses throughout the menstrual cycle (30, 33). This is explained by the distinct hormonal content (either FSH and LH alone or both) of the secretory vesicles subtypes, secretory granin content and proximity to the membrane surface $(30,33)$. Secretoneurin, a secretogranin derivate, was demonstrated by electron microscopy as co-stored with GH in secretory vesicles and constitutively secreted from retinal ganglion cells, but unlike $\mathrm{GH}$ lacking a stimulatory response to GHRH in vitro (32).

Table 3 AIP values at baseline and during ITT.

\begin{tabular}{lll}
\hline & & \multicolumn{1}{c}{ GHD $(n=13)$} \\
\cline { 1 - 2 }$P_{0 \text { min }}(n g / m L)$ & & $0.155(0.129-0.203)$ \\
$\operatorname{AIP}_{30 \text { min }}(n g / m L)$ & & $0.140(0.99-0.385)$ \\
$\operatorname{AIP}_{60 \text { min }}(n g / m L)$ & & $0.198(0.127-0.299)$ \\
$\operatorname{AIP}_{90 \text { min }}(\mathrm{ng} / \mathrm{mL})$ & & $0.192(0.084-0.331)$ \\
$\operatorname{AIP}_{120 \text { min }}(\mathrm{ng} / \mathrm{mL})$ & & $0.155(0.133-0.405)$ \\
$P^{a}$ & 0.962
\end{tabular}

\begin{tabular}{l}
\hline \multicolumn{1}{c}{ NGHD $(n=31)$} \\
\hline $0.143(0.087-0.339)$ \\
$0.210(0.128-0.341)$ \\
$0.245(0.119-0.382)$ \\
$0.173(0.103-0.511)$ \\
$0.160(0.088-0.375)$ \\
0.174
\end{tabular}

\begin{tabular}{c}
\hline \multicolumn{1}{c}{ All $(n=44)$} \\
\hline $0.149(0.097-0.332)$ \\
$0.204(0.120-0.367)$ \\
$0.214(0.121-0.377)$ \\
$0.181(0.096-0.397)$ \\
$0.158(0.105-0.398)$ \\
0.293
\end{tabular}

Data are expressed as median and interquartile range.

aFriedman test.

https://ec.bioscientifica.com

https://doi.org/10.1530/EC-19-0082 (c) 2019 The authors Published by Bioscientifica Ltd

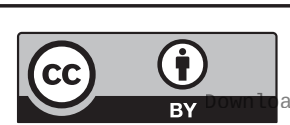

This work is licensed under a Creative Commons Attribution 4.0 International License. ded from Bioscientifica.com at 04/26/2023 10:05:42AM 


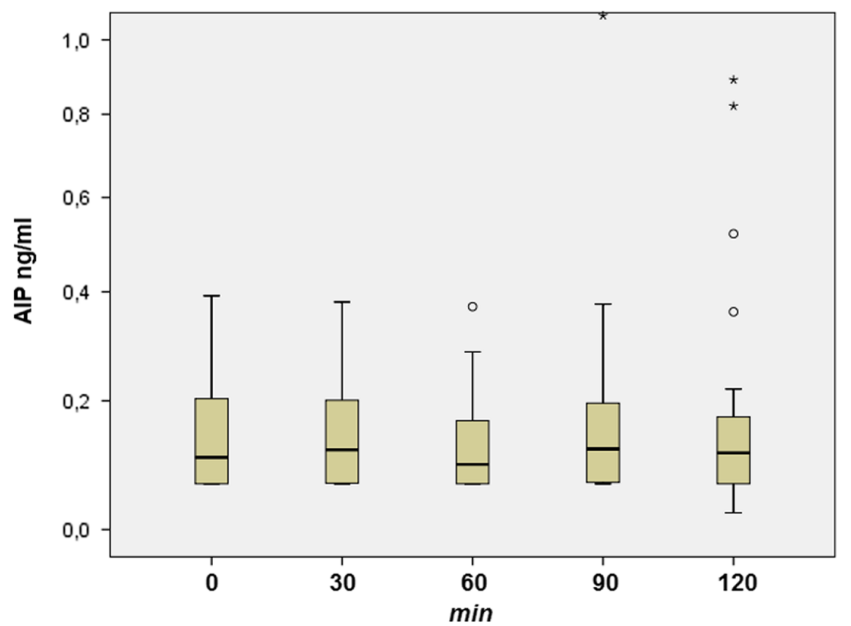

Figure 4

Serum AIP (ng/mL, log scale) in 0, 30, 60, 90 and 120 min of OGTT (all 44 tested subjects).

Galanin, a modulatory neuropeptide, was co-localized within healthy and adenomatous human corticotrophs and rodent lactotrophs, somatotrophs and thyrotrophs. In vitro $\mathrm{GH}$ and galanin were secreted from mutated rat pituitary cells. However, co-secretion of galanin and anterior pituitary hormones was absent, attributable either to their release under different stimuli or a limited contribution of pituitary secretion to overall circulating galanin $(34,35)$.

Given the ubiquitous nature of AIP expression, the contribution of pituitary-origin AIP to circulating AIP might be negligible. The presence of measurable serum AIP similar to the cohort's average even in our two patients with complete anterior pituitary deficiency (one with additional posterior pituitary deficiency) supports this possible explanation. Data from studies screening all human organs confirmed AIP mRNA expression in 36 studied tissues (37). We have recently identified a role of AIP in lymphocytes, which could be a source of circulating AIP (38). A close correlation between AIP and GH levels may not be expected due to their highly discrepant half-lives, being in the order of $30 \mathrm{~h}$ for AIP

Table 4 AIP values at baseline and during OGTT. compared to only $16 \mathrm{~min}$ for GH (10). The long half-life of AIP advocates that it should be measurable peripherally as well as centrally. However, petrosal venous sampling with central to peripheral gradient analysis could better confirm or refute pituitary as the source of circulating AIP.

AIP might have a predominantly autocrine or paracrine effect (perhaps on GH secretion modulation) and the measurable circulating levels might purely result from cell death or damage-related leakage rather than a regulated secretory event. AIP does lack some of the typical secreted peptide characteristics, such as a signal peptide or glycosylation sites. However, there are several other compounds known to be secreted without glycosylation sites (e.g. ferritin) or without signal peptides (e.g. FGF1 or IL-6) including members of the same immunophilin family that AIP belongs to, such as FKBPL and cyclophilin A $(25,39)$. In endocrine cells, co-secreted molecules which are not part of the main prohormone are usually produced in amounts 100-1000-fold smaller than the main secreted product, baring largely autocrine or paracrine actions. However, the circulatory serum AIP concentrations measured in our study were consistently of the same order of magnitude as the circulatory GH.

GH stimulation during ITT is predominantly mediated at the supra-hypothalamic level resulting in GHRH release and somatostatin inhibition, with a smaller effect directly at the pituitary level (40). Other GH secretagogues, such as ghrelin could, theoretically, be missed by using hypoglycaemia as a test stimulus and this could have an effect on AIP release. In addition, the well-described heterogeneity of GH cell subpopulations with different susceptibility to releasing stimulants could perhaps result in discrepant co-secretion (41).

The first recognized partner of AIP is the nuclear receptor AhR, known to bind environmental toxins. The role of the AhR-AIP pathway has been studied in pituitary cells and patients with acromegaly $(42,43,44,45,46$, $47,48)$. Several in vitro studies have related exposure to AhR-mediated toxins in GH3 cells to an increase in either proliferation (47) or GH secretion (48). An epidemiological

\begin{tabular}{|c|c|}
\hline & $\mathbf{A A}(n=26)$ \\
\hline $\mathrm{AIP}_{0 \min }(\mathrm{ng} / \mathrm{mL})$ & $0.097(0.068-0.151)$ \\
\hline $\operatorname{AIP}_{30 \mathrm{~min}}(\mathrm{ng} / \mathrm{mL})$ & $0.110(0.069-0.184)$ \\
\hline $\operatorname{AIP}_{60 \mathrm{~min}}(\mathrm{ng} / \mathrm{mL})$ & $0.076(0.068-0.189)$ \\
\hline $\operatorname{AIP}_{90 \min }(\mathrm{ng} / \mathrm{mL})$ & $0.105(0.084-0.197)$ \\
\hline $\operatorname{AIP}_{120 \min }(\mathrm{ng} / \mathrm{mL})$ & $0.104(0.068-0.155)$ \\
\hline$p^{a}$ & 0.118 \\
\hline
\end{tabular}

\begin{tabular}{l}
\hline \multicolumn{1}{c}{ NGHS $(n=18)$} \\
\hline $0.153(0.069-0.293)$ \\
$0.148(0.068-0.224)$ \\
$0.125(0.102-0.145)$ \\
$0.127(0.068-0.190)$ \\
$0.126(0.068-0.361)$ \\
0.152
\end{tabular}

\begin{tabular}{c}
\hline \multicolumn{1}{c}{ All $(n=44)$} \\
\hline $0.108(0.068-0.204)$ \\
$0.120(0.068-0.178)$ \\
$0.096(0.068-0.178)$ \\
$0.121(0.068-0.196)$ \\
$0.114(0.068-0.175)$ \\
0.188
\end{tabular}

Data are expressed as median and interquartile range.

aFriedman test.

https://ec.bioscientifica.com

https://doi.org/10.1530/EC-19-0082 (c) 2019 The authors Published by Bioscientifica Ltd

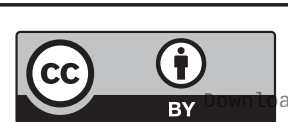

This work is licensed under a Creative Commons Attribution 4.0 International License. ded from Bioscientifica.com at 04/26/2023 10:05:42AM 
Table 5 Correlation of baseline and dynamic AIP and GH values in ITT.

\begin{tabular}{|c|c|}
\hline & Baseline AIP (ng/mL) \\
\hline GHD & $0.155(0.112-0.326)$ \\
\hline \multirow[t]{2}{*}{ NGHD } & $0.143(0.087-0.339)$ \\
\hline & $\operatorname{AIPmax}(\mathrm{ng} / \mathrm{mL})$ \\
\hline$\overline{G H D}$ & $0.292(0.160-0.587)$ \\
\hline \multirow[t]{2}{*}{ NGHD } & $0.278(0.146-0.562)$ \\
\hline & AIP AUC (ng/mL/120 min) \\
\hline$\overline{\mathrm{GHD}}$ & $25.90(13.03-50.03)$ \\
\hline NGHD & $24.58(13.32-46.46)$ \\
\hline
\end{tabular}

\begin{tabular}{c}
\hline Baseline GH $(\mathrm{ng} / \mathrm{mL})$ \\
\hline $0.28 \pm 0.06$ \\
$0.45 \pm 0.11$ \\
\hline GH $\max (\mathrm{ng} / \mathrm{mL})$ \\
\hline $1.42 \pm 0.22$ \\
$15.09 \pm 1.12$ \\
\hline GH AUC $(\mathrm{ng} / \mathrm{mL} / 120 \mathrm{~min})$ \\
\hline $89.78 \pm 13.82$ \\
$952.44 \pm 78.15$
\end{tabular}

\begin{tabular}{c}
\hline $\boldsymbol{R}$ \\
\hline 0.121 \\
0.440 \\
\hline $\boldsymbol{R}$ \\
\hline 0.385 \\
0.008 \\
\hline $\boldsymbol{R}$ \\
\hline 0.462 \\
0.198
\end{tabular}

\begin{tabular}{c}
\hline $\boldsymbol{P}$ \\
\hline 0.694 \\
0.816 \\
\hline $\boldsymbol{P}$ \\
\hline 0.194 \\
0.967 \\
\hline $\boldsymbol{P}$ \\
\hline 0.112 \\
0.286
\end{tabular}

Data are expressed as median and interquartile range (AIP values) or as mean and S.E. (GH values).

$R$, Spearman's Rho.

association was proposed between exposition to environmental pollution and somatotropinoma incidence (43), although no direct link was found in the area with an inductrial accident involving dioxin (42). AHR and AIP genetic variants were studied in acromegaly patients to investigate whether they have a modifying effect together with pollution exposure on adenoma size, biochemical severity and resistance to somatostatin analogues (45). Individual history of exposure to xenobiotics might also influence the secretory response of AIP. We have not collected these data on our pituitary patients in this study. It is conceivable that the degree of AhR involvement in detoxification could impact intracellular AIP distribution, and consequently its secretion. Circulating human AIP analysis might find potential application in the expanding field of endocrine disruptor chemicals research.

Our results leave open the question of the physiological significance of circulating AIP, but provide a solid platform of a reliable in vivo human circulatory serum AIP protein immunometric assay measurement to be used for further research. The independence of circulating AIP levels from age, gender and BMI and considerable circulatory stability and autonomy from severe hypoglycaemia or hyperglycaemia are demonstrated, as well as independence from the GH, PRL and cortisol secretory dynamics in ITT and from GH secretory dynamics in OGTT.

\section{Conclusion}

Serum levels of AIP were reliably measured in the circulation by a novel immunometric assay. Serum AIP levels are found to be independent of age, sex or BMI and unaffected by hypoglycaemia or hyperglycaemia. A rise in serum GH, ACTH and cortisol or PRL is not accompanied by serum AIP concentration change. Contrary to expectations based on secretory vesicles co-localization studies, neither constitutive nor stimulated co-secretion of AIP and GH

Table 6 Correlation of baseline and dynamic AIP and GH values in OGTT.

\begin{tabular}{|c|c|}
\hline & Baseline AIP (ng/mL) \\
\hline AA & $0.096(0.067-0.159)$ \\
\hline \multirow[t]{2}{*}{ NGHS } & $0.153(0.068-0.302)$ \\
\hline & Baseline AIP (ng/mL) \\
\hline$\overline{\mathrm{AA}}$ & 0.096 (0.067-0.159) \\
\hline \multirow[t]{2}{*}{ NGHS } & $0.153(0.068-0.302)$ \\
\hline & AIPmax (ng/mL) \\
\hline$\overline{\mathrm{AA}}$ & $0.190(0.106-0.247)$ \\
\hline \multirow[t]{2}{*}{ NGHS } & $0.190(0.132-0.415)$ \\
\hline & AIP AUC (ng/mL/120 min) \\
\hline$\overline{\mathrm{AA}}$ & $12.85(9.97-22.16)$ \\
\hline \multirow[t]{2}{*}{ NGHS } & $16.63(10.46-26.00)$ \\
\hline & AIP AUC (ng/mL/120 $\mathrm{min})$ \\
\hline$\overline{\mathrm{AA}}$ & $12.85(9.97-22.16)$ \\
\hline NGHS & $16.63(10.46-26.00)$ \\
\hline
\end{tabular}

\begin{tabular}{c}
\hline Baseline GH $(\mathrm{ng} / \mathrm{mL})$ \\
\hline $14.73 \pm 3.25$ \\
$0.56 \pm 0.08$ \\
\hline Nadir GH $(\mathrm{ng} / \mathrm{mL})$ \\
\hline $11.27 \pm 2.90$ \\
$0.29 \pm 0.05$ \\
\hline GH $\max (\mathrm{ng} / \mathrm{mL})$ \\
\hline $17.23 \pm 3.46$ \\
$0.82 \pm 0.18$ \\
\hline GH AUC $(\mathrm{ng} / \mathrm{mL} / 120 \mathrm{~min})$ \\
\hline $1692.46 \pm 378.23$ \\
$52.57 \pm 7.71$ \\
\hline Nadir GH $(\mathrm{ng} / \mathrm{mL})$ \\
\hline $11.27 \pm 2.90$ \\
$0.29 \pm 0.05$ \\
\hline
\end{tabular}

\begin{tabular}{c}
\hline $\boldsymbol{R}$ \\
\hline 0.061 \\
0.204 \\
\hline $\boldsymbol{R}$ \\
\hline 0.079 \\
0.140 \\
\hline $\boldsymbol{R}$ \\
\hline 0.195 \\
0.087 \\
\hline $\boldsymbol{R}$ \\
\hline 0.263 \\
0.176 \\
\hline $\boldsymbol{R}$ \\
\hline 0.273 \\
0.141
\end{tabular}

\begin{tabular}{c}
\hline $\boldsymbol{P}$ \\
\hline 0.768 \\
0.416 \\
\hline $\boldsymbol{P}$ \\
\hline 0.702 \\
0.580 \\
\hline $\boldsymbol{P}$ \\
\hline 0.340 \\
0.731 \\
\hline $\boldsymbol{P}$ \\
\hline 0.194 \\
0.484 \\
$\boldsymbol{P}$ \\
\hline 0.178 \\
0.577
\end{tabular}

Data are expressed as median and interquartile range (AIP values) or as mean and S.E. (GH values).

$R$, Spearman's Rho.

https://ec.bioscientifica.com

https://doi.org/10.1530/EC-19-0082 (c) 2019 The authors Published by Bioscientifica Ltd

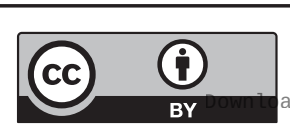

This work is licensed under a Creative Commons Attribution 4.0 International License. ded from Bioscientifica.com at 04/26/2023 10:05:42AM 
is observed. As this conserved protein is necessary for survival, a platform of reliable immunometric serum AIP measurement is key for further research of its circulatory source, role and impact.

\section{Supplementary data}

This is linked to the online version of the paper at https://doi.org/10.1530/ EC-19-0082.

\section{Declaration of interest}

The authors declare that there is no conflict of interest that could be perceived as prejudicing the impartiality of the research reported.

\section{Funding}

This work was supported by the Serbian Ministry of Science (Project number 175033), and by research visit grants to MS from Society for Endocrinology (Practical Skills Grant), Royal College of Physicians (Samuel Leonard Simpson Fellowship), British Society for Neuroendocrinology (Research Visit Grant) and European Society of Endocrinology (Short Term Fellowship). CES was supported by a Wellcome Clinical Training Fellowship (Grant no 097970/Z/11/Z).

\section{Acknowledgements}

The authors are grateful to Drs Chrisostomos Prodromou and Rhodri Morgan (Sussex University, UK) for the preparation of AIP protein. C Strasburger and M Korbonits contributed equally to the study.

\section{References}

1 Vierimaa O, Georgitsi M, Lehtonen R, Vahteristo P, Kokko A, Raitila A, Tuppurainen K, Ebeling TM, Salmela PI, Paschke R, et al. Pituitary adenoma predisposition caused by germline mutations in the AIP gene. Science 2006312 1228-1230. (https://doi.org/10.1126/ science.1126100)

2 Daly AF, Vanbellinghen JF, Khoo SK, Jaffrain-Rea ML, Naves LA, Guitelman MA, Murat A, Emy P, Gimenez-Roqueplo AP, Tamburrano G, et al. Aryl hydrocarbon receptor-interacting protein gene mutations in familial isolated pituitary adenomas: analysis in 73 families. Journal of Clinical Endocrinology and Metabolism 200792 1891-1896. (https://doi.org/10.1210/jc.2006-2513)

3 Leontiou CA, Gueorguiev M, van der Spuy J, Quinton R, Lolli F, Hassan S, Chahal HS, Igreja SC, Jordan S, Rowe J, et al. The role of the aryl hydrocarbon receptor-interacting protein gene in familial and sporadic pituitary adenomas. Journal of Clinical Endocrinology and Metabolism 200893 2390-2401. (https://doi.org/10.1210/jc.20072611)

4 Ibanez-Costa A \& Korbonits M. AIP and the somatostatin system in pituitary tumours. Journal of Endocrinology 2017235 R101-R116. (https://doi.org/10.1530/JOE-17-0254)

5 Lin BC, Sullivan R, Lee Y, Moran S, Glover E \& Bradfield CA. Deletion of the aryl hydrocarbon receptor-associated protein 9 leads to cardiac malformation and embryonic lethality. Journal of Biological Chemistry 2007282 35924-35932. (https://doi.org/10.1074/jbc.M705471200)

6 Aflorei ED, Klapholz B, Chen C, Radian S, Dragu AN, Moderau N, Prodromou C, Ribeiro PS, Stanewsky R \& Korbonits M. In vivo bioassay to test the pathogenicity of missense human AIP variants. Journal of Medical Genetics 201855 522-529. (https://doi. org/10.1136/jmedgenet-2017-105191)
7 Linnert M, Haupt K, Lin YJ, Kissing S, Paschke AK, Fischer G, Weiwad M \& Lucke C. NMR assignments of the FKBP-type PPIase domain of the human aryl-hydrocarbon receptor-interacting protein (AIP). Biomolecular NMR Assignments 20126 209-212. (https://doi org/10.1007/s12104-012-9359-0)

8 Morgan RM, Hernández-Ramírez LC, Trivellin G, Zhou L, Roe SM, Korbonits M \& Prodromou C. Structure of the TPR domain of AIP: lack of client protein interaction with the C-terminal alpha-7 helix of the TPR domain of AIP is sufficient for pituitary adenoma predisposition. PLOS ONE 20127 e53339. (https://doi.org/10.1371/ journal.pone.0053339)

9 Trivellin G \& Korbonits M. AIP and its interacting partners. Journal of Endocrinology 2011210 137-155. (https://doi.org/10.1530/ JOE-11-0054)

10 Hernández-Ramírez LC, Martucci F, Morgan RM, Trivellin G, Tilley D, Ramos-Guajardo N, Iacovazzo D, D'Acquisto F, Prodromou C \& Korbonits M. Rapid proteasomal degradation of mutant proteins is the primary mechanism leading to tumorigenesis in patients with missense AIP mutations. Journal of Clinical Endocrinology and Metabolism 2016101 3144-3154. (https://doi. org/10.1210/jc.2016-1307)

11 Ma Q \& Whitlock JP. A novel cytoplasmic protein that interacts with the $\mathrm{AH}$ receptor, contains tetratricopeptide repeat motifs, and augments the transcriptional response to 2,3,7,8-tetrachlorodibenzop-dioxin. Journal of Biological Chemistry 1997272 8878-8884. (https://doi.org/10.1074/jbc.272.14.8878)

12 Carver LA \& Bradfield CA. Ligand-dependent interaction of the aryl hydrocarbon receptor with a novel immunophilin homolog in vivo. Journal of Biological Chemistry 1997272 11452-11456. (https://doi. org/10.1074/jbc.272.17.11452)

13 Meyer BK \& Perdew GH. Characterization of the AhR-hsp90-XAP2 core complex and the role of the immunophilin-related protein XAP2 in AhR stabilization. Biochemistry 199938 8907-8917. (https:// doi.org/10.1021/bi982223w)

14 Fagerberg L, Hallstrom BM, Oksvold P, Kampf C, Djureinovic D, Odeberg J, Habuka M, Tahmasebpoor S, Danielsson A, Edlund K, et al. Analysis of the human tissue-specific expression by genomewide integration of transcriptomics and antibody-based proteomics. Molecular and Cellular Proteomics 201413 397-406. (https://doi. org/10.1074/mcp.M113.035600)

15 Hernandez-Ramirez LC, Morgan RML, Barry S, D'Acquisto F, Prodromou C \& Korbonits M. Multi-chaperone function modulation and association with cytoskeletal proteins are key features of the function of AIP in the pituitary gland. Oncotarget 20189 9177-9198. (https://doi.org/10.18632/oncotarget.24183)

16 Beckers A, Aaltonen LA, Daly AF \& Karhu A. Familial isolated pituitary adenomas (FIPA) and the pituitary adenoma predisposition due to mutations in the aryl hydrocarbon receptor interacting protein (AIP) gene. Endocrine Reviews 201334 239-277. (https://doi. org/10.1210/er.2012-1013)

17 Hernández-Ramírez LC, Gabrovska P, Dénes J, Stals K, Trivellin G, Tilley D, Ferraù F, Evanson J, Ellard S, Grossman AB, et al. Landscape of familial isolated and young-onset pituitary adenomas: prospective diagnosis in AIP mutation carriers. Journal of Clinical Endocrinology and Metabolism 2015100 E1242-E1254. (https://doi.org/10.1210/ jc.2015-1869)

18 Daly AF, Tichomirowa MA, Petrossians P, Heliovaara E, Jaffrain-Rea ML, Barlier A, Naves LA, Ebeling T, Karhu A, Raappana A, et al. Clinical characteristics and therapeutic responses in patients with germ-line AIP mutations and pituitary adenomas: an international collaborative study. Journal of Clinical Endocrinology and Metabolism 201095 E373-E383. (https://doi.org/10.1210/ jc.2009-2556)

19 Kasuki L, Vieira Neto L, Wildemberg LE, Colli LM, de Castro M, Takiya CM \& Gadelha MR. AIP expression in sporadic somatotropinomas is a predictor of the response to octreotide LAR

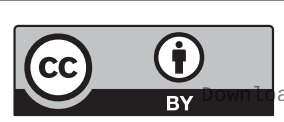

This work is licensed under a Creative Commons Attribution 4.0 International License. 
therapy independent of SSTR2 expression. Endocrine-Related Cancer 201219 L25-L29. (https://doi.org/10.1530/ERC-12-0020)

20 Formosa R, Xuereb-Anastasi A \& Vassallo J. Aip regulates cAMP signalling and GH secretion in GH3 cells. Endocrine-Related Cancer 201320 495-505. (https://doi.org/10.1530/ERC-13-0043)

21 Lecoq AL, Viengchareun S, Hage M, Bouligand J, Young J, Boutron A, Zizzari P, Lombes M, Chanson P \& Kamenicky P. AIP mutations impair AhR signaling in pituitary adenoma patients fibroblasts and in GH3 cells. Endocrine-Related Cancer 201623 433-443. (https://doi. org/10.1530/ERC-16-0041)

22 Chen S, Liang MC, Chia JN, Ngsee JK \& Ting AE. Rab8b and its interacting partner TRIP8b are involved in regulated secretion in att20 cells. Journal of Biological Chemistry 2001276 13209-13216. (https://doi.org/10.1074/jbc.M010798200)

23 Chen B, Liu P, Hujber EJ, Li Y, Jorgensen EM \& Wang ZW. AIP limits neurotransmitter release by inhibiting calcium bursts from the ryanodine receptor. Nature Communications 20178 1380. (https://doi. org/10.1038/s41467-017-01704-z)

24 Henderson B \& Pockley AG. Molecular chaperones and proteinfolding catalysts as intercellular signaling regulators in immunity and inflammation. Journal of Leukocyte Biology 201088 445-462. (https://doi.org/10.1189/jlb.1209779)

25 Zhang M, Tang J, Yin J, Wang X, Feng X, Yang X, Shan H, Zhang Q, Zhang J \& Li Y. The clinical implication of serum cyclophilin A in patients with chronic obstructive pulmonary disease. International Journal of Chronic Obstructive Pulmonary Disease 201813 357-363. (https://doi.org/10.2147/COPD.S152898)

26 Valentine A, O'Rourke M, Yakkundi A, Worthington J, Hookham M, Bicknell R, McCarthy HO, McClelland K, McCallum L, Dyer H, et al. FKBPL and peptide derivatives: novel biological agents that inhibit angiogenesis by a CD44-dependent mechanism. Clinical Cancer Research 201117 1044-1056. (https://doi.org/10.1158/1078-0432. CCR-10-2241)

27 Thrush AB, Antoun G, Nikpay M, Patten DA, DeVlugt C, Mauger JF, Beauchamp BL, Lau P, Reshke R, Doucet É, et al. Diet-resistant obesity is characterized by a distinct plasma proteomic signature and impaired muscle fiber metabolism. International Journal of Obesity 201842 353-362. (https://doi.org/10.1038/ijo.2017.286)

28 Ho KK \& 2007 GH Deficiency Consensus Workshop Participants. Consensus guidelines for the diagnosis and treatment of adults with GH deficiency II: a statement of the GH Research Society in association with the European Society for Pediatric Endocrinology, Lawson Wilkins Society, European Society of Endocrinology, Japan Endocrine Society, and Endocrine Society of Australia. European Journal of Endocrinology 2007157 695-700. (https://doi.org/10.1530/ EJE-07-0631)

29 Katznelson L, Laws ER, Jr, Melmed S, Molitch ME, Murad MH, Utz A, Wass JA \& Endocrine Society. Acromegaly: an endocrine society clinical practice guideline. Journal of Clinical Endocrinology and Metabolism 201499 3933-3951. (https://doi.org/10.1210/jc.20142700)

30 Stamatiades GA \& Kaiser UB. Gonadotropin regulation by pulsatile GnRH: signaling and gene expression. Molecular and Cellular Endocrinology 2018463 131-141. (https://doi.org/10.1016/j. mce.2017.10.015)

31 Wang Z, You J, Xu S, Hua Z, Zhang W, Deng T, Fang N, Fang Q Liu H, Peng L, et al. Colocalization of insulin and glucagon in insulinoma cells and developing pancreatic endocrine cells. Biochemical and Biophysical Research Communications 2015461 598-604. (https://doi.org/10.1016/j.bbrc.2015.04.072)

32 Martinez-Moreno CG, Trudeau VL \& Harvey S. Co-storage and secretion of growth hormone and secretoneurin in retinal ganglion cells. General and Comparative Endocrinology 2015220 124-132. (https://doi.org/10.1016/j.ygcen.2014.11.012)

33 Abel MH, Widen A, Wang X, Huhtaniemi I, Pakarinen P, Kumar TR $\&$ Christian HC. Pituitary gonadotrophic hormone synthesis, secretion, subunit gene expression and cell structure in normal and follicle-stimulating hormone beta knockout, follicle-stimulating hormone receptor knockout, luteinising hormone receptor knockout, hypogonadal and ovariectomised female mice. Journal of Neuroendocrinology 201426 785-795. (https://doi.org/10.1111/ jne.12178)

34 Moore JP, Jr, Cai A, Maley BE, Jennes L \& Hyde JF. Galanin within the normal and hyperplastic anterior pituitary gland: localization, secretion, and functional analysis in normal and human growth hormone-releasing hormone transgenic mice. Endocrinology 1999140 1789-1799. (https://doi.org/10.1210/ endo.140.4.6648)

35 Ceresini G, Marchini L, Fabbo A, Freddi M, Pasolini G, Reali N, Troglio G \& Valenti G. Evaluation of circulating galanin levels after exercise-induced pituitary hormone secretion in man. Metabolism: Clinical and Experimental 199746 282-286. (https://doi.org/10.1016/ S0026-0495(97)90254-7)

36 Nilsson O, Bilchik AJ, Goldenring JR, Ballantyne GH, Adrian TE \& Modlin IM. Distribution and immunocytochemical colocalization of peptide YY and enteroglucagon in endocrine cells of the rabbit colon. Endocrinology 1991129 139-148. (https://doi.org/10.1210/ endo-129-1-139)

37 Su AI, Wiltshire T, Batalov S, Lapp H, Ching KA, Block D, Zhang J, Soden R, Hayakawa M, Kreiman G, et al. A gene atlas of the mouse and human protein-encoding transcriptomes. PNAS 2004101 6062-6067. (https://doi.org/10.1073/ pnas.0400782101)

38 Sun D, Stopka-Farooqui U, Barry S, Aksoy E, Parsonage G, Vossenkamper A, Capasso M, Wan X, Norris S, Marshall JL, et al. AIP maintains germinal center B cells through suppression of BCL6 degradation. Cell Reports 2019 [in press].

39 Yakkundi A, Bennett R, Hernandez-Negrete I, Delalande JM, Hanna M, Lyubomska O, Arthur K, Short A, McKeen H, Nelson L, et al. FKBPL is a critical antiangiogenic regulator of developmental and pathological angiogenesis. Arteriosclerosis, Thrombosis, and Vascular Biology 201535 845-854. (https://doi.org/10.1161/ ATVBAHA.114.304539)

40 Salvatori R, Serpa MG, Parmigiani G, Britto AV, Oliveira JL, Oliveira CR, Prado CM, Farias CT, Almeida JC, Vicente TA, et al. $\mathrm{GH}$ response to hypoglycemia and clonidine in the GH-releasing hormone resistance syndrome. Journal of Endocrinological Investigation 200629 805-808. (https://doi.org/10.1007/ BF03347374)

41 Dobado-Berrios PM, Ruiz-Navarro A, Lopez-Pedrera R, Gonzalez de Aguilar JL, Torronteras R, Hidalgo-Diaz C \& Gracia-Navarro F. Heterogeneity of growth hormone (GH)-producing cells in aging male rats: in vitro GH releasing activity of somatotrope subpopulations. Molecular and Cellular Endocrinology 1996123 127-137. (https://doi.org/10.1016/S03037207(96)03906-8)

42 Pesatori AC, Baccarelli A, Consonni D, Lania A, Beck-Peccoz P, Bertazzi PA \& Spada A. Aryl hydrocarbon receptor interacting protein and pituitary adenomas: a population-based study on subjects exposed to dioxin after the Seveso, Italy, accident. European Journal of Endocrinology 2008159 699-703. (https://doi.org/10.1530/ EJE-08-0593)

43 Cannavo S, Ferraù F, Ragonese M, Curto L, Torre ML, Magistri M, Marchese A, Alibrandi A \& Trimarchi F. Increased prevalence of acromegaly in a highly polluted area. European Journal of Endocrinology 2010163 509-513. (https://doi.org/10.1530/ EJE-10-0465)

44 Cannavo S, Ferrau F, Ragonese M, Romeo PD, Torre ML, Puglisi S, De Menis E, Arnaldi G, Salpietro C, Cotta OR, et al. Increased frequency of the rs2066853 variant of aryl hydrocarbon receptor gene in patients with acromegaly. Clinical Endocrinology 201481 249-253. (https://doi.org/10.1111/cen.12424)

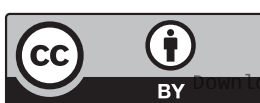

This work is licensed under a Creative Commons Attribution 4.0 International License. 
45 Cannavo S, Ragonese M, Puglisi S, Romeo PD, Torre ML, Alibrandi A Scaroni C, Occhi G, Ceccato F, Regazzo D, et al. Acromegaly is more severe in patients with AHR or AIP gene variants living in highly polluted areas. Journal of Clinical Endocrinology and Metabolism 2016 101 1872-1879. (https://doi.org/10.1210/jc.2015-4191)

46 Cannavo S, Trimarchi F \& Ferrau F. Acromegaly, genetic variants of the aryl hydrocarbon receptor pathway and environmental burden. Molecular and Cellular Endocrinology 2017457 81-88. (https://doi. org/10.1016/j.mce.2016.12.019)
47 Tapella L, Sesta A, Cassarino MF, Zunino V, Catalano MG \& Pecori Giraldi F. Benzene and 2-ethyl-phthalate induce proliferation in normal rat pituitary cells. Pituitary 201720 311-318. (https://doi. org/10.1007/s11102-016-0777-3)

48 Fortunati N, Guaraldi F, Zunino V, Penner F, D'Angelo V, Zenga F, Pecori Giraldi F, Catalano MG \& Arvat E. Effects of environmental pollutants on signaling pathways in rat pituitary GH3 adenoma cells. Environmental Research 2017158 660-668. (https://doi.org/10.1016/j. envres.2017.07.015

Received in final form 18 February 2019

Accepted 4 March 2019

Accepted Preprint published online 4 March 2019

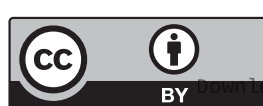

This work is licensed under a Creative Commons Attribution 4.0 International License.

ded from Bioscientifica.com at 04/26/2023 10:05:42AM 